\title{
Grape Seed Extract and the Fetal Ductus Arteriosus: A Potential Danger of a Common Herbal Supplement
}

\author{
Brian Benjamin, Marcus Schamberger, Eric Ebenroth \\ Department of Pediatrics, Section of Pediatric Cardiology, 705 Riley Hospital Drive, Indiana University School of Medicine, \\ Indianapolis, IN, USA \\ Email: eebenrot@iu.edu
}

How to cite this paper: Benjamin, B., Schamberger, M. and Ebenroth, E. (2016) Grape Seed Extract and the Fetal Ductus Arteriosus: A Potential Danger of a Common Herbal Supplement. International Journal of Clinical Medicine, 7, 685-689.

http://dx.doi.org/10.4236/ijcm.2016.710074

Received: July 22, 2016

Accepted: October 24, 2016

Published: October 27, 2016

Copyright (C) 2016 by authors and Scientific Research Publishing Inc. This work is licensed under the Creative Commons Attribution International License (CC BY 4.0)

http://creativecommons.org/licenses/by/4.0/

\begin{abstract}
A female at 28 weeks gestation was referred to pediatric cardiology for a fetal arrhythmia. The echocardiogram revealed premature constriction of the fetal ductus arteriosus. Her work up was unremarkable except for her use of an herbal supplement, grape seed extract, which is advertised as a potent anti-inflammatory medication, and has biochemical properties similar to other medications that have been shown to cause premature ductal constriction. The use of herbal remedies increases each year. Although the public is inundated with radio, television, and internet advertisements for these products, little unbiased information regarding the possible dangers of toxicity or adverse reactions exists. As physicians, we need to be aware of these products, and counsel our patients accordingly.
\end{abstract}

\section{Keywords}

Grape Seed Extract, Prenatal Medications, Ductus Arteriosus, Cardiology, Herbal Remedies

\section{Introduction}

In a recent study, more than one-third of Americans polled reported trying some form of alternative medicine at least once [1]. This is hardly surprising since homeopathy is a familiar concept to older Americans, many of whom grew up taking home-grown family cold and flu remedies. The younger generation, although accustomed to more conventional medical management, is continually flooded with television and magazine advertisements declaring the medical efficacy of "natural" treatments. In addition, widespread use of the internet makes both the information and the availability of homeo- 
pathic medications readily accessible to cyber-savvy patients. Very few websites, however, offer consumers accurate and unbiased information regarding the potential dangers of toxicity or adverse reactions from these products. Although many herbal supplements are harmless in sensible doses, some may exhibit unfavorable or even toxic effects in certain patient populations. We will present a case that illustrates constriction of the fetal ductus arteriosus associated with maternal consumption of grape seed extract, a common homeopathic supplement. Informed consent was not obtained prior to the writing of this report.

\section{Case}

A 36-year-old G2, P1 at 28 weeks gestation was referred to Pediatric Cardiology for a fetal echocardiogram due to a fetal arrhythmia detected during a routine sonogram. She was rubella immune, VDRL nonreactive, hepatitis B surface antigen negative, and group B streptococcus negative. There was no history of maternal infections and she initially reported taking no medications during this pregnancy. Due to advanced maternal age, an amniocentesis was performed during the second trimester and revealed a normal $46 \mathrm{XX}$ fetus with no detectable chromosomal abnormalities. The mother's past medical history was significant only for mild aortic regurgitation. She denied any use of tobacco, alcohol, or recreational drugs. The fetal echocardiogram revealed a structurally normal heart, but was significant for constriction of the ductus arteriosus (Figure 1). There was right-to-left shunting with Doppler velocity of $1.5 \mathrm{~m} / \mathrm{sec}$ indicating premature ductal constriction. No fetal arrhythmia was detected. Upon further questioning about diet and medication practices, she denied use of non-steroidal anti-inflammatory drugs (NSAIDs) but admitted to taking grape seed extract. Her husband was a staunch believer in homeopathy and he encouraged her to take the herbal supplement because

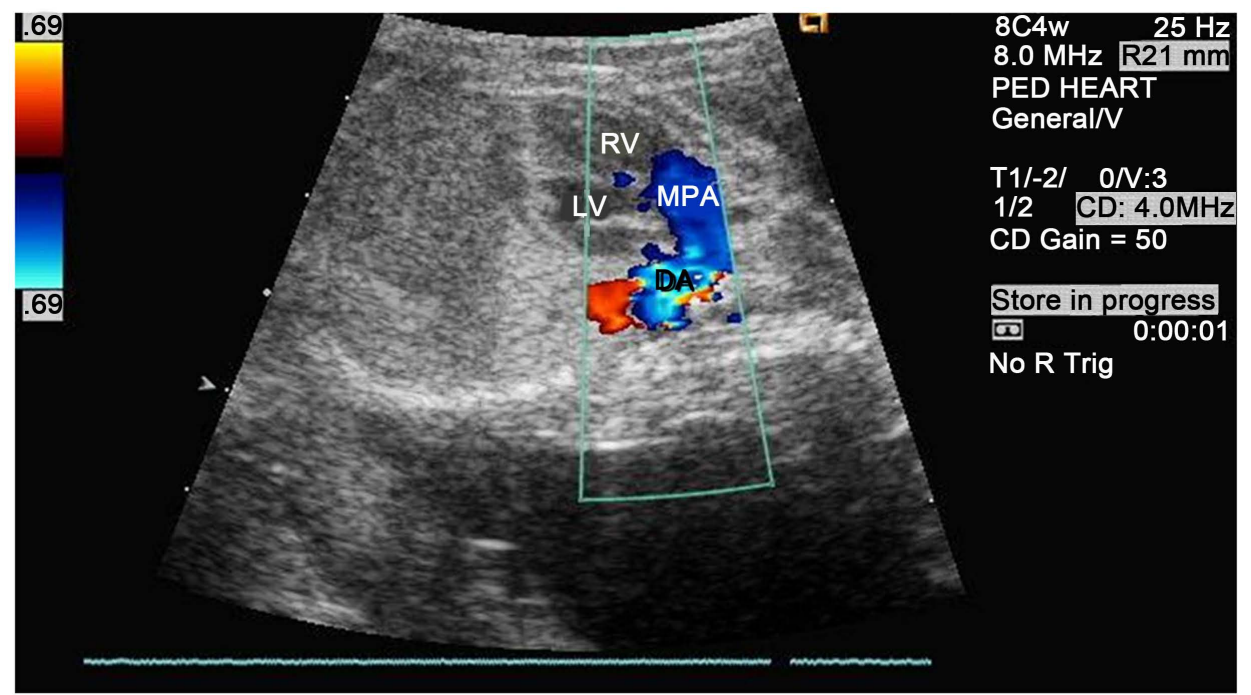

Figure 1. 2D/Color Doppler fetal echocardiographic image showing turbulence in the ductus arteriosus consistent with premature ductal construction. RV: right ventricle, LV: left ventricle, MPA: main pulmonary artery, DA: ductus arteriosus. 
he felt it would "be good for her heart." It is unclear as to how long she had been taking the supplement prior to presentation. She was advised by the echocardiography physician to discontinue her use of the grape seed extract. A repeat fetal echocardiogram four weeks later at 32 weeks gestation revealed worsening premature ductal constriction with a Doppler velocity of $1.8 \mathrm{~m} / \mathrm{sec}$. Although she claimed to have discontinued use of the grape seed extract, her furtive glances at her husband, and his vehement, bordering on belligerent, insistence that these substances are "natural and perfectly safe", when questioned as to whether she had stopped taking the product, suggested otherwise.

They refused to return for follow up fetal echocardiography and the pregnancy progressed without further complications. The patient gave birth to a healthy, term-baby via uncomplicated spontaneous vaginal delivery. The neonate weighed $3.6 \mathrm{~kg}$ and had Apgar scores of 8 and 9 at 1 and 5 minutes respectively and was discharged home with the mother on postpartum day of life two without complications.

\section{Discussion}

During fetal life, the ductus arteriosus shunts blood from the pulmonary circulation to the systemic circulation. Direction of fetal ductal flow is determined by low resistance within the aortic (umbilical-placental) circulation and high resistance within the pulmonary artery circulation. Immediately following the first breath at birth, the lungs expand and pulmonary vascular resistance drops. The pressure gradient along the ductus reverses as the pulmonary circulation becomes the low pressure system and the systemic circulation becomes the high pressure system. As a result, there is a reversal of flow within the ductus, exposing the vessel to oxygenated blood. The increased oxygen tension predisposes the ductus to constriction. Once the umbilical cord is cut, the ductus loses the placental source of vasodilators and the remaining prostaglandins in the circulation are quickly metabolized within the lungs [2]. Functional closure of the ductus typically occurs within 10 to 18 hours and is mediated by constriction of smooth muscle cells. Severe constriction or functional closure of the ductus arteriosus before birth can lead to pulmonary hypertension, which can be a source of severe post-natal morbidity and death [3].

Grape seed extract contains a variety of compounds, the most important of which are the bioflavonoids and procyanidins. According to recent research, these natural compounds possess antioxidant and free radical scavenging activity that may prove useful in the treatment of a variety of illnesses [4]. Additionally, advertisements claim that grape seed extract possesses potent anti-inflammatory activities. Studies have demonstrated that the anti-inflammatory activity of the procyanidins works through inhibition of prostaglandin production by direct inhibition of the enzyme cyclooxygenase [5]. This is the same mechanism of action found in the class of drugs known as NSAIDs. It has been previously shown in both animal and human studies that inhibition of prostaglandin synthesis during pregnancy produces premature ductal constriction [6] [7]. Koren et al. demonstrated that the use of NSAIDs in pregnant women was associated 
with a 15-fold increase in the incidence of premature ductal constriction [8].

The manufacturers of herbal remedies and supplements in the United States are not federally regulated like the pharmaceutical industry. Consequently, many unsubstantiated claims are made concerning the benefits of these substances, and the companies are not required to list or report any potential adverse effects. The American Academy of Pediatrics had shown support for the Dietary Supplement Information Act, which would have required tighter federal regulation of all dietary supplements [9]. Under this act, all involved in the manufacture, packing, and distribution of dietary supplements would have been required to register with the FDA, submit a product label for approval, and report any adverse effects associated with their products. Unfortunately, this act was never passed into law.

This is the first reported case in which a dietary supplement taken by a pregnant patient may have resulted in constriction of the fetal ductus arteriosus. Although the patient was instructed to discontinue taking the grape seed extract, the clinical picture and the results of the second fetal echocardiogram were highly suggestive of her noncompliance. Be that as it may, this case illustrates the potential adverse effects that can be caused by "natural" dietary supplements. Until the federal government begins to regulate herbal remedies and dietary supplements, and mandates reporting of adverse events, physicians and consumers alike need to view these products with caution.

The case demonstrated the potential dangerous effects that herbal remedies can have on a pregnancy. As most patients do not consider these products to be medications, physicians must routinely inquire about their patients' diet, and specifically about dietary supplement use, when taking a detailed history. It is important for physicians to be aware of these products and of potential side effects that can occur from their use in order to properly educate their patients. Physicians should emphasize that the effects of natural supplements are, at present, not fully understood and that one should seek appropriate medical advice before purchasing or taking herbal remedies, just as one would for prescription or non-prescription medications.

\section{References}

[1] Barnes, P.M., Bloom, B. and Nahin, R.L. (2008) Complementary and Alternative Medicine Use among Adults and Children: United States, 2007. National Health Statistics Report, No. 12, National Center for Health Statistics, Hyattsville, MD.

[2] Smith, G.C. (1998) The Pharmacology of the Ductus Arteriosus. Pharmacological Reviews, 50, 35-58.

[3] Gewillig, M., et al. (2009) Premature Foetal Closure of the Arterial Duct: Clinical Presentations and Outcome. European Heart Journal, 30, 1530-1536. http://dx.doi.org/10.1093/eurheartj/ehp128

[4] Bagchi, D., et al. (2000) Free Radicals and Grape Seed Proanthocyanidin Extract: Importance in Human Health and Disease Prevention. Toxicology, 148, 187-197. http://dx.doi.org/10.1016/S0300-483X(00)00210-9

[5] Zhang, W.Y., et al. (2006) Procyanidin Dimer B2 [Epicatechin-(4beta-8)-epicatechin] Suppresses the Expression of Cyclooxygenase-2 in Endotoxin-Treated Monocytic Cells. Bio- 
chemical and Biophysical Research Communications, 345, 508-515.

http://dx.doi.org/10.1016/j.bbrc.2006.04.085

[6] Moise Jr., K.J. (1993) Effect of Advancing Gestational Age on the Frequency of Fetal Ductal Constriction in Association with Maternal Indomethacin Use. American Journal of Obstetrics and Gynecology, 168, 1350-1353. http://dx.doi.org/10.1016/S0002-9378(11)90763-7

[7] Van den Veyver, I.B., et al. (1993) The Effect of Gestational Age and Fetal Indomethacin Levels on the Incidence of Constriction of the Fetal Ductus Arteriosus. Obstetrics \& Gynecology, 82, 500-503.

[8] Koren, G., et al. (2006) Nonsteroidal Antiinflammatory Drugs during Third Trimester and the Risk of Premature Closure of the Ductus Arteriosus: A Meta-Analysis. Annals of Pharmacotherapy, 40, 824-829. http://dx.doi.org/10.1345/aph.1G428

[9] Meier, P. (2001) Academy Endorses Legislation to Regulate All Dietary Supplements. American Academy of Pediatrics News.

Submit or recommend next manuscript to SCIRP and we will provide best service for you:

Accepting pre-submission inquiries through Email, Facebook, LinkedIn, Twitter, etc. A wide selection of journals (inclusive of 9 subjects, more than 200 journals)

Providing 24-hour high-quality service

User-friendly online submission system

Fair and swift peer-review system

Efficient typesetting and proofreading procedure

Display of the result of downloads and visits, as well as the number of cited articles

Maximum dissemination of your research work

Submit your manuscript at: http://papersubmission.scirp.org/

Or contact ijcm@scirp.org 